\title{
SOCIAL-HYGIENIC MONITORING OF MORBIDITY BY PSORIASIS UNDER CONDITIONS OF THE ZAPOROZHSKY INDUSTRIAL REGION
}

\author{
${ }^{1}$ Sevalnev A.I., ${ }^{1}$ Sokolovskaya I.A., ${ }^{1}$ Makurina G.I., ${ }^{2}$ Tsymbal V.A. \\ ${ }^{1}$ Zaporozhye State Medical University, Zaporozhye, Ukraine \\ ${ }^{2}$ Zaporizhye State Engineering Academy, Zaporozhye, Ukraine \\ irinasokol10@meta.ua
}

Relevance. The high prevalence of psoriasis among the population of the earth $(0.1-7.0 \%)$, as well as the difficulty of its treatment, necessitate the development of new methods for its prevention and increasing the effectiveness of treatment.

Objective. To study the peculiarities of the incidence of psoriasis in the population of the Zaporozhye region under the influence of unfavorable environmental factors.

Methods. Under supervision in 2012, there were 5475 patients with psoriasis, of whom 2439 (44.5\%) were women, 2731 (49.9\%) were men and 305 (5.6\%) were children. In 2013, there were 5635 patients with psoriasis, of whom 2504 (44.4\%) were women, 2818 $(50.0 \%)$ were men and $313(5.6 \%)$ were children.

Results. The highest levels of psoriasis in the Zaporozhye region are registered in Zaporozhye, Gulyaypol, Veselovsky, Kuibyshev, Primorsk and Vasilievsky districts. In these administrative units, the prevalence of psoriasis was within $269.6-513.8 \mathrm{cl}$. / 100 thousand, significantly higher than the average regional level $(\mathrm{p}<0.05)$, the prevalence of psoriasis in Zaporozhye (by 146.1 180.6 sl. / 100 thousand), in Gulyaypol district (by 96.1 - 141.9 cases / 100 thousand), and Veselovsky district (by 84.9 - 105.9 cases / 100 thousand).

Conclusions: For the first time, a systematic approach to the analysis of the incidence of psoriasis with regard to environmental factors was used, in order to achieve stable remission in patients with active psoriasis, it is necessary to correct exogenous and endogenous trigger factors in order to minimize their effects.

Key words: socio-hygienic monitoring, psoriasis, environmental factors

Introduction. According to the International Federation of Psoriasis Associations, the prevalence of psoriasis in the world varies between $1.2-5 \%$ in general populations, with an average prevalence of about $3 \%$ [1]. Among $2-3 \%$ of the population of European countries there are various forms of psoriasis [2]. The prevalence in Western European countries is more than $2 \%$. In other European countries, the prevalence of psoriasis does not exceed $6 \%$ of the total population: in Ireland - 5.5\%, in Scotland - 4.8\%, Spain - 3.7\%, Sweden $-2.3 \%$, Norway $-2.0 \%$. In the US and Canada, these figures are $2.2 \%-4.6 \%$ and $4.7 \%$ respectively. In the former USSR, the incidence of psoriasis among the general population was $2 \%$ [3]. The most common form of the disease is plaque psoriasis. The epidemiological, clinical and social significance of psoriasis in modern conditions is difficult to overestimate [4]. Psoriasis in all its various clinical forms is one of the most common chronic inflammatory skin diseases. For most patients, the disease means long-term restrictions in various aspects of daily life with huge personal costs, sometimes with severe stigma and discrimination. The socio-economic consequences of psoriasis are associated with chronization, a decline in labor productivity and a significant cost of treatment.
Objective. To study the peculiarities of the incidence of psoriasis in the population of the Zaporozhye region under the influence of unfavorable environmental factors.

\section{MATERIAL AND METHODS}

The assessment of atmospheric pollution in Zaporozhye was carried out in accordance with the requirements of clause 8 of DSP-201-97 "State sanitary rules for the protection of atmospheric air in populated areas (against pollution by chemical and biological substances)", by comparing the total pollutant (Y PO) substances with an indicator of maximum permissible pollution (GDZ). shows that the pollution level of the ambient air by the criterion of the pollution level indicator remains "unacceptable", and by the degree of danger - "moderately dangerous". Hygienic methods of investigation of atmospheric atmospheric pollution by aspiration method. The method is based on the stretching of air through absorbing media that are capable of delaying substances to be determined. The choice of the absorbing medium depends on the aggregate state of the substances. To absorb substances that are in the air in the gaseous state or in the form of a vapor, special solutions or solid sorbents (activated 
carbon, silica gel) are used. Aerosols (smoke, dust, fog) are caught by various filtering materials. Air sampling using a filter. To filter airborne highly dispersed aerosols: fumes, fogs, dust - use a variety of filter materials: paper and membrane filters, filters consisting of a fine fibrous material, FPP-15 (Petryanova filters), glass porous filters of different numbers, glass or mineral wool. It is most expedient to use analytical aerosol filters of the AFA brand. To carry out a weight or chemical analysis of aerosols, filters with a working area of $10 \mathrm{cmI}$ (AFA-B-10) and $18 \mathrm{cmI}$ (AFA-B -18) are used. Before weighing after sampling, the filters are placed in a thermostat at a temperature of $55-60{ }^{\circ} \mathrm{C}$ for 20 to 30 minutes or a desiccator for at least 2 hours, then kept at room temperature for an hour. For the chemical analysis, filters AFA-XA, AFA-XM, AFA$\mathrm{XC}$ are used. Reduction to normal conditions is carried out according to the formula:

$$
\mathrm{V}=\left(V_{-} \mathrm{t} \text { Ч } 273 \text { Ч В) / ((273-t) Ч } 07600\right) \text {, }
$$

where, $\mathrm{V}$ - the volume of air under normal conditions;

$\mathrm{Vt}$ is the volume of air determined at sampling;

$t$ is the air temperature when sampling;

$\mathrm{B}$ - atmospheric pressure when sampling.

To assess the quality of atmospheric air, drinking water and soil, corresponding annual reports, protocols of research of the centers of sanitary and epidemiological surveillance, and departmental laboratories were used. Along with this, the task of determining the technogenic burden on a particular territory was solved with the identification of the share of the branches of the national economy in the total load. For this purpose, the data characterizing the number of point (wells, barns, warehouses, etc.), area (enterprises, sewage pumping stations, commodity parks, car parks, etc.) and linear (pipelines of oil, gas, sewage, brines, water, etc.) sources of environmental pollution. To identify the causal relationship of public health with environmental factors, modern statistical methods are used, including component analysis and evaluation of derived variables, their mean errors, reliability of the difference in indicators, standardized indicators, pair correlation analysis. To assess the complex influence of environmental factors, an approach based on comparison of the average characteristics of its individual factors with the corresponding mid-regional indicators taken as a standard (standard) is used. This allows the transition in calculations to dimensionless indicators, expressed in conditional scores. All patients received informed consent to participate in the research. Under supervision in 2012, there were 5475 patients with psoriasis. Of these, $2439(44.5 \%)$ are women, 2731 (49.9\%) are men and $305(5.6 \%)$ are children. In 2013, there were 5635 patients with psoriasis. Of these, 2504 (44.4\%) are women, $2818(50.0 \%)$ are men and 313
(5.6\%) are children. The study sample included patients aged 1 to 65 years (mean age $38.6 \pm 2.21$ years) with a diagnosis of psoriasis common in the ICD 10. The study did not include patients with addiction to psychoactive substances (drug addiction), with severe abnormalities (according to laboratory indices) and severe somatic condition, required correction of somatotropic therapy and / or determining a high (according to experts) risk of exacerbation of somatic pathology during the study, pregnant or breast-feeding.

\section{RESULTS AND THEIR DISCUSSION}

A characteristic feature of the Zaporozhye Oblast is the relative stability of the concentration of harmful substances in the atmospheric air, their extremely slow decrease as they move away from the source of emissions [5]. The diversified industry in the region and the high concentration of production in cities determine the enormous environmental impact on the scale. In connection with the foregoing, the study of environmental pollution and its impact on skin incidence of the population is an actual hygienic problem. Characteristics of the prevalence of psoriasis in the Zaporozhye region. The prevalence of psoriasis in the Zaporozhye region is presented in Table 1. As can be seen, among the entire population, its highest levels are registered in the city of Zaporozhye, Gulyaypol, Veselovsky, Kuibyshev, Primorsk and Vasilievsky districts. In these administrative units, the prevalence of psoriasis was in the range of 269.6 $513.8 \mathrm{pl} . / 100$ thous. However, the spatial prevalence of psoriasis is inherent in the regularity of its levels. In particular, the prevalence of psoriasis in the city of Zaporozhye (by 146.1 - 180.6/100,000), in the Gulyaypol district (by 96.1 - 141.9 sl. / 100 thousand), and Veselovsky district (by 84.9 - 105.9 cases / 100 thousand). The lower $(\mathrm{p}<0.05)$ levels are statistically significant in the Volnyansky District (by 314.5 - 324.7 / 100k) and in the Berdyansk District (274.9 - 294.2 / $100 \mathrm{k})$. In this case, the prevalence of psoriasis during 2012 - 2013 years. was at a stable level. So, in Zaporozhye it was 497.9 - $513.8 \mathrm{cl} . / 100$ thousand, in Gulyaypol district - 443.6 - $475.1 \mathrm{sl} / 100$ thousand, in the Veselovsky district - 417.5 - 438.0 sl ./100 thousand.

Analysis of environmental parameters in the framework of socio-hygienic monitoring [6]. The adverse environmental situation in Ukraine significantly affects the morbidity and mortality of the population. 3 times lower than in the whole CIS countries, population growth, 2 to 2.5 times higher than in developed countries, infant mortality, a reduction of 5 to 7 years of life expectancy - all this is evidence of urgent measures. It is known that among the causes determining the level of morbidity, the state of the environment occupies about $20 \%$, and if we talk in 
Sevalnev A.I., Sokolovskaya I.A., Makurina G.I., Tsymbal V.A.

Prevalence of psoriasis in the Zaporozhye region in 2012-2013 among the whole population

Table 1

\begin{tabular}{|c|c|c|c|c|}
\hline \multirow[b]{2}{*}{ Administrative unit } & \multicolumn{2}{|r|}{2012 year } & \multicolumn{2}{|r|}{2013 year } \\
\hline & abs. & $\begin{array}{c}\text { distribution of } \\
\text { nennost, } \\
\text { grade / } 100 \text { thousand }\end{array}$ & abs. & $\begin{array}{c}\text { distribution of } \\
\text { nennost, } \\
\text { grade / } 100 \text { thousand }\end{array}$ \\
\hline Zaporozhye & 4106 & 497.9 & 4215 & 513.8 \\
\hline Melitopol & 230 & 110.9 & 237 & 114.4 \\
\hline Energodar & 120 & 219.2 & 124 & 227.3 \\
\hline Berdyanskiy & 76 & 53.3 & 80 & 56.4 \\
\hline Novonikolaevsky & 41 & 245.6 & 44 & 266.9 \\
\hline Kuibyshevsky & 74 & 316.3 & 65 & 281.1 \\
\hline Akimovsky & 60 & 173.4 & 62 & 180.0 \\
\hline Volnyansky & 11 & 22.8 & 9 & 18.7 \\
\hline Kamensk-Dneprovsky & 37 & 89.6 & 42 & 102.4 \\
\hline Chernigovsky & 39 & 218.7 & 44 & 250.5 \\
\hline Tokmak & 62 & 107.3 & 55 & 95.9 \\
\hline Veselovsky & 93 & 417.5 & 97 & 438.0 \\
\hline Gulyaypolsky & 123 & 443.6 & 130 & 475.1 \\
\hline Rozovsky & 10 & 106.6 & 11 & 118.6 \\
\hline Primorsky & 84 & 269.6 & 93 & 300.7 \\
\hline Vasilievsky & 180 & 272.5 & 188 & 286.2 \\
\hline Priazovsky & 58 & 202.9 & 63 & 222.3 \\
\hline Pologovsky & 44 & 105.7 & 43 & 104.3 \\
\hline Total & 5448 & 332.6 & 5602 & 332.1 \\
\hline
\end{tabular}

general about the current ecological tension in combination with stress and neuropsychic overloads, then, according to $\mathrm{WHO}$, the derivative of all this is a large part diseases - up to $70-80 \%$. Among many factors that affect human health, one of the main places is occupied by atmospheric pollution and the quality of drinking water. Currently, 1327 sources of centralized drinking water supply are operated in the Zaporozhye region (in 2012 - 1318), 474 drinking-water pipelines, including 53 municipal, 39 departmental, 381 rural and 1 inter-district, 853 wells (2012 - 791). Most of the settlements in Berdyansk, Vasilievsky, Gulyaypol, Melitopol, Mikhailovsky, Pologovsky, and Priazovsky districts use drinking water that does not meet hygienic standards for organoleptic properties and sanitary and chemical indicators (mineralization, elevated concentrations of iron, manganese). One of the dominant adverse environmental factors is atmospheric air. Industrial emissions into the atmosphere of Ukraine annually reach 11 million tons, which is $20-25 \%$ of the total emission in the whole of the CIS countries. During 2013, laboratories of the Sanitary and Epidemiological Service of Zaporozhye Oblast carried out 13345 atmospheric air surveys (in 2012 - 18447), $4.22 \%$ exceeded the maximum permissible concentrations (in 2012, these exceedances were $5.66 \%)$.

\section{CONCLUSIONS}

The etiology and pathogenesis of psoriasis have not been adequately studied. Currently, psoriasis is considered a multifactorial disease, in the genesis of which both the hereditary factor and numerous environmental factors play a role: environmental conditions, including those associated with urbanization, low living standards, eating disorders, increased contact with aggressive chemicals, acting either directly on the skin, or mediated through the respiratory and digestive systems. Materials of sociohygienic monitoring of the incidence of psoriasis among various groups of urban and rural population in the Zaporozhye region should be used to develop management decisions to protect the air and water basin from man-made pollution, improve the quality of drinking water and food, and improve the quality of public health services.

Конфлікт інтересів. Автори заявляють, що не мають конфлікт інтересів, який може сприйматися таким, що може завдати шкоди неупередженості статті.

Джерело фінансування. Ця стаття не отримала фінансової підтримки від державної, громадської або комірційної організації. 


\section{REFERENCES}

1. Alpatova I.A. Models and algorithms of the estimation of the influence of the ecological and hygienic situation of the industrial region on the incidence of the population on skin diseases // Medical Informatics and Engineering. 2009. P. 57-61.

2. Alpatova I.A., Bashmakov D.G. Interconnection of some ecological and climatic factors and the incidence of psoriasis // Dermatovenereology. Cosmetology. Sexual pathology. 2000. P. 116-120.

3. Alpatova I.A., Horvaia A.I., Sarychev A.P. Method of forecasting the morbidity of the population of an industrial megapolis in view of the state of the habitat // Ukrainian Journal of Medical Technology and Technology. 2001. P. 51-57.
4. Bashmakov D.G. Features of the course and therapy of psoriasis in urban residents. Author's abstract. Dis kanda honey, sciences. Kharkiv. 2003. P. 20.

5. Bocharov V.A., M. Alavni, S.M. Tarnopolskaya. Regulatory factors of the inflammatory-reparative process in chronic recurrent dermatoses // Ukrainian Journal of Dermatology, Venereology, Cosmetology. 2003. P. 18-21.

6. Dykova O.V., Devaev A.C. Role of free radicals and the state of endotoxicosis in the pathogenesis of psoriasis and eczema // Sovrem. methods of diagnosis and treatment in medicine. Tula. 2001. P. 11-47.

Отримано: 26.06.2017

\title{
СОЦІАЛЬНО-ГІГІЕНІЧНИЙ МОНІТОРИНГ ЗАХВОРЮВАНОСТІ НА ПСОРІАЗ В УМОВАХ ЗАПОРІЗЬКОГО ПРОМИСЛОВОГО РЕГІОНУ
}

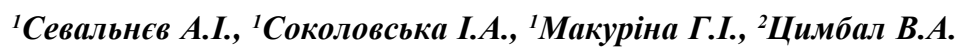

${ }^{1}$ Запорізький державний медичний університет, Запоріжжя, Украӥна

2Запорізька державна інженерна академія, Запоріжж, Україна

Актуальність: висока поширеність псоріазу серед населення землі (0,1-7,0\%), а також труднощі його лікування, викликають необхідність розробки новітніх методів його профілактики та підвищення ефективності лікування.

Мета: вивчити особливості захворюваності на псоріаз населення Запорізької області в умовах впливу несприятливих факторів навколишнього середовища.

Матеріали та методи. Під наглядом в 2012 році перебували 5475 хворих на псоріаз, з них 2439 (44,5\%) осіб - жінки, 2731 (49,9\%) - чоловіки і 305 (5,6\%) - дітей. У 2013 р - 5635 хворих на псоріаз, з них 2504 (44,4\%) осіб - жінки, 2818 (50,0\%) чоловіки і 313 (5,6\%) - дітей. Для оцінки якості атмосферного повітря, питної води і грунту були використані відповідні щорічні звіти, протоколи досліджень центрів санітарно-епідеміологічного нагляду, а також відомчих лабораторій.

Результати: виявлено незадовільну якість питної води та високий рівень атмосферних забруднень в Запорізькій області. Найбільш високі рівні поширеності псоріазу в Запорізькій області зареєстровано в м. Запоріжжі, Гуляйпільському, Веселівському, Куйбишевському, Приморському та Василівському районах. У зазначених адміністративних одиницях поширеність псоріазу знаходилася в межах 269,6 - 513,8 вип. / 100 тис, достовірно вище середньообласного рівня $(\mathrm{p}<0,05)$ поширеність псоріазу в м. Запорожжі (на 146,1 - 180,6 вип. / 100 тис), в Гуляйпільському районі (на 96,1 - 141,9 вип. / 100 тис), і Веселівському районі (на 84,9 - 105,9 вип. / 100 тис).

Висновки. Вперше використано системний підхід до аналізу захворюваності на псоріаз з урахуванням екологічних чинників. Для досягнення стійкої ремісії у пацієнтів з псоріазом обов'язково здійснювати корекцію екзогенних і ендогенних тригерних факторів з метою мінімізації їх впливу.

Ключові слова: соціально-гігієнічний моніторинг, псоріаз, фактори навколишнього середовища.

\section{СОЦИАЛЬНО-ГИГИЕНИЧЕСКИЙ МОНИТОРИНГ ЗАБОЛЕВАЕМОСТИ ПСОРИАЗОМ В УСЛО- ВИЯХ ЗАПОРОЖСКОГО ПРОМЫШЛЕННОГО РЕГИОНА}

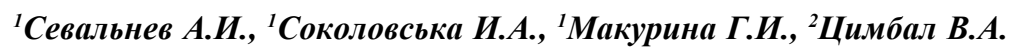 \\ 'Запорожский государственный медицинский университет, Запорожье, Украина \\ 2Запорожская государственная инженерная академия, Запорожье, Украина
}

Актуальность: высокая распространенность псориаза среди населения земли (0,1-7,0\%), а также трудности его лечения,
Цель: изучить особенности заболеваемости псориазом населения Запорожской области в условиях воздействия неблагоп-
риятных факторов окружающей среды.
Материалы и методы. Под наблюдением в 2012 году находились 5475 больных псориазом, из них $2439(44,5 \%)$ человек
женщины, 2731 (49,9\%) - мужчины и 305 (5,6\%) - дети. В 2013 г. - 5635 больных псориазом, из них $2504(44,4 \%)$ человек -
енщины, 2818 (50,0\%) - мужчины и $313(5,6 \%)$ - дети. Для оценки качества атмосферного воздуха, питьевой воды и почвы 
были использованы соответствующие ежегодные отчеты, протоколы исследований центров санитарно-эпидемиологического надзора, а также ведомственных лабораторий.

Результаты. Выявлено неудовлетворительное качество питьевой воды и высокий уровень атмосферных загрязнений в Запорожской области. Наиболее высокие уровни распространенности псориаза в Запорожской области зарегистрировано в г. Запорожье, Гуляйпольском, Веселовском, Куйбышевском, Приморском и Васильевском районах. В указанных административных единицах распространенность псориаза находилась в пределах 269,6-513,8 случаев / 100 тыс достоверно выше среднеобластного уровня ( $<20,05)$ распространенность псориаза в г. Запорожье (на 146,1-180,6 случаев / 100 тыс), в Гуляйпольском районе (на 96,1-141,9 случаев / 100 тыс), и Веселовском районе (на 84,9-105,9 случаев / 100 тыс).

Выводы. Впервые использован системный подход к анализу заболеваемости псориазом с учетом экологических факторов. Для достижения устойчивой ремиссии у пациентов с псориазом обязательно осуществлять коррекцию экзогенных и эндогенных триггерных факторов с целью минимизации их влияния.

Ключевые слова: социально-гигиенический мониторинг, псориаз, факторы окружающей среды. 